Marija Najdić, The College of Tourism, Belgrade, Serbia

Tamara Lukić, Singidunum University, Belgrade, Serbia

Tatjana Ilić Kosanović, School of Engineering Management, Belgrade, Serbia

UDC 338.487:659.127.6

005.346:338.48

\title{
LOYALTY PROGRAMS (FPS) IN TOURISM: IMPORTANCE OF LONG TERM RELATIONSHIP WITH CUSTOMERS
}

\begin{abstract}
This paper emphasizes the significance of developing long-term relationships with customers through the introduction of loyalty programs in everyday businesss. The paper further presents a link between the creation of a solid consumer base and their value in providing stable profits to companies for a longer period of time. Thus, in order to better understand the importance of customer lifetime value, authors gave a simple example how companies could calculate potential profit of a single consumer. Also, the paper explains the principle of CRM
\end{abstract}

\section{Introduction}

Success in the market depends on continuous improvement of customer relations since a stable relationship is one of the key factors in their retaining. Satisfied customers display considerable loyalty in the long run, they are more likely to use different services of the same company, show higher flexibility on price changes and also give their opinion on the improvement of services and the ways that would contribute to their loyalty. According to a Marketing Metrics study by Griffin and Lowenstein (2002), the average company has a $60-70 \%$ probability of a successful sale to active customers; a $20-40 \%$ probability of a sale to lost customers; and only a $5-20 \%$ probability of a sale to prospects (Griffin J., Lowenstein W. M., 2002).

Everyone who offers a unique and pleasant experience to consumers, can expect and presents the rules in creating incentives for customers to engage in frequent purchases of tourism products. Especially, authors of this paper highlight the need of developing frequency programs (FPs) as a guideline in creation of customized relationships with customers, using examples from companies operating in the tourism sector.

Keywords: Loyalty, CRM, tourism, Customer Lifetime Value, Frequency programs (FPs)

a purchase to end up with mutual satisfaction, because "consumer satisfaction is the best indicator of future profits of the company" (Smith P., 2002:491). Moreover, the consumer remembers the experience and the personal relationship with the service company for a longer period of time, more than remembering the price and conditions of payment.

Value perceived from customers' perspective (Customer Perceived Value) is the difference between all the benefits and costs of all the possible alternatives to be considered and assessed by the potential consumer (Kotler P., Keller Kevin L., 2006:141). One of the main challenges is certainly the intangibility and abstraction of tourism services, thus the inability to gain experience of the service before its consumption. In this regard, personnel and environment play an important role, which gives a special dimen- 
sion to the consumers overall impression and perception. Therefore, the communication with customers must continue after their purchase, due to the influence on the overall experience, and possible changes in their behavior towards a long-term relationships and loyalty.

A large number of products are goods in mass selling and easily subjected to substitution (Lindstrom M., 2007). This also applies to services which can easily be copied but, at the same time, can also be innovated in order to become unique and original. In that sense, the product is anything that can be offered to the market in order to satisfy the wishes and needs of consumers. Each product has 5 levels where each level adds more value to the customer, thus making hierarchy of values for the customer (Kotler P., Keller Kevin L., 2006:372). The first and basic level is the essence of utility, respectively service or benefit that the customer actually buys. On the second level there is a basic product, i.e. all elements that the product consists of. A set of attributes that customers expect when they make a purchase is the third level of the products and cover their minimum expectations. Especially significant is the fourth level or so called "expanded product" that exceeds customer expectations. This level leads to a differentiation of the product and allows the positioning of the brand and competitiveness. The last level is a "potential product" which covers all possible expansions and transformations that could happen in the future to the product.

Businesses are looking for new ways to satisfy customers and make their offer special and unique. This requires a significant financial investment and additional costs that are not affordable to everyone. Or in our case, to create a long-term relationship of consumers and companies, in order to avoid higher investment and ensure a secure market with the third and fourth level of the product.

\section{The importance of Customer Loyalty}

Customers have shown different levels of loyalty towards certain companies. Loyalty is defined as "a deep-seated belief that they re-buy or continue to constantly use the product or service that is favored, despite external influence and marketing efforts that could lead to behavior change". The key for winning the loyalty lies in providing value to customers (Kotler P., Keller Kevin L., 2006:143). Loyalty can't be measured, predicted, or bought. It is the result of a series of factors that build trust. A sense of predictability and security play a big role in a world where everything is changing.

From the perspective of consumers, a higher level of loyalty means stronger sense of belonging and relationship with a particular company, reduced costs, risks, and confirmation of their own lifestyle. In this way, consumers have an active connection and relationship with the company on an emotional level (Evans M. et al., 2006). When loyalty is based on, for example, lower cost of products, it is usually with limited duration.

Keaveney has identified more than 800 critical points in the behavior of service companies that prompted consumers to change their decision in choosing a company. All the reasons are grouped into 8 categories (Keaveney S., 1995):

1. Technical errors in the delivery of services;

2. A negative impression of the company's employees;

3. The inability of employees to solve the problem;

4. Increases in prices;

5. Inaccessible location, working hours, long waiting for an appointment;

6. Better offer of competitors;

7. Unethical, illegal and immoral behavior of companies and

8. Other reasons (change of address, etc.). 
For a tourism company, importance of customer loyalty is reflected in the repeated purchase and profit that follows. Also, these consumers are less sensitive to price, because their trust gives them reason to pay a higher price than the average. In the economic aspect of the business, it is less expensive to keep existing customers than to attract a new for several reasons (Evans M., et al., 2006:277):

- Investment in developing long-term relationships is lower than investments in attracting new consumers, primarily through the promotion of new services;

- Consumers are more experienced and therefore they need less help and information;

- They spread positive word of mouth (WOM) which is more trustful than traditional advertising;

- They are open for cooperation and willing to share good and bad news with the company in order to help.

Consequently, a single consumer has a certain benefits for retention in:

- Receiving the appropriate value and quality of service;

- Trust and reliability, a sense of familiarity and belonging, creating closer links and friendships with a person who deliver the service;

- Special discounts and rewards.

It is clear that the benefits from loyalty have both positive sides, the tourism companies and their consumers. If we look at the consumer value, from a strategic point of view, we should take into consideration the long-term or life value, which is the projection of the consumer value to the company in the long term, since the current situation does not have to be a guarantee that the consumer will continue to have unchanged behavior (Veljković S., 2006:190-195).

The research confirms the facts that are important for customer retention (loyalty): winning new customers can cost five times more than the cost of retaining existing ones. Kotler stated that if the rate of customers outflow decreased by $5 \%$, profit can be increased by $25 \%$ up to $85 \%$ depending on the sector, i.e. the profit rate from consumers shows a tendency to increase during the lifetime of retained customers (Kotler P., Keller Kevin L., 2006:156). Reichheld points out, however, that if company reduce consumers outflow for $10-15 \%$, profit could be doubled (Reichheld F., 1996). The challenge in applying the concept of lifetime value (Customer Lifetime Value) is to reach reliable estimate of costs and revenues.

The importance of consumers lifetime value for tourism company is often seen throughout a frequent use of the loyalty term. In fact, customer loyalty is "life value" of company. If we take, for example, that on average tourists travel every two years on holiday with the same tour company, choosing a similar travel arrangement, over the next 20 years, he will perform 10 purchases. If we assume that, tourist purchases accommodation service and transportation service in a package with total price of $€ 230$ (periodic value), customer value for the period of 10 years is $€ 2.300$. By implementing this analysis in the tourism company which obtains $40 \%$ of the revenue from the provision of providing accommodation and transport services (excluding taxes, subagent fees ranging from 7-15\%, employee's salaries and rents), it is clear that, the potential value of a single customer for the period 20 years is $€$ 4,600 , that is $€ 1,840$ of an agency profit.

There is a growing fluctuation of customers due to fact that many travel agencies focus on the achievement of sales instead of building relationships with customers and care about them after purchase, when they return from holiday (Kotler P., Keller Kevin L., 2006). Search for a new way to retain consumers, have led some tourism companies to adopt the principles of Total Quality TQM (Total Quality Management). Principles relate to the improvement of the process of creating and providing services and 
building closer relationships with customers CRM (Customer Relationship Management).

\section{Managing Relationship with Customers (CRM)}

Establishing stronger relationships with customers is a process of obtaining and managing detailed information about each consumer individually. By having these information, companies can adjust their products, services, programs and awards to a specific market segment.

The importance of Customer Relationship Management is in the fact that the main driver of company profitability is the value of its customer base (Kotler P., Keller Kevin L., 2006:152-153). Relationship marketing concept was first introduced by Berry in 1983 . He defined it as "the attracting, keeping and improving relationships with customers." Term marketing relationship Kotler viewed as: "the practice of building long-term satisfied relationships with key parties..." and this can be achieved with "promises and deliveries of high-quality service with fair price between the parties over a longer time." It is believed, however, that the most complete definition was presented by Groenross who says: Relationship Marketing (CRM) represents identification, establishment, development and retaining (and, if necessary, stopping) relationships with customers and other stakeholders, gaining a profit, in a way to meet the objectives of all sides, which is achieved by a common exchange and fulfilling promises (Veljković S., 2006:184). Hence, companies that want to create strong relationships with customers must comply to following basic rules (Aaker D.,et al. 2008:694):

- Achieving cross sectoral engagement in the planning and managing satisfaction processes and retaining customers;

- Taking into consideration "consumer voice" in order to determine their expressed and unexpressed needs or re- quirements regarding all decisions in business;

- The creation of superior products, services and experiences for the target market;

- Organization and accessibility of information from the database about an individual customer needs, their preferences, contacts, purchase frequency and satisfaction;

- Helping the customers to reach the right people in the company and to express their needs, perceptions and complaints;

- Keeping employee reward program for honoring prominent individuals.

The goal of customer relationship management (CRM) is that the company employees create added value for consumers. Aaker had presented three drivers of value for customers: value evaluation, brand value and relationship value (Aaker D., et al., 2008:684-685):

- Value evaluation is customers objective assessment about offer benefits based on their perception of the benefits versus the costs. Sub drivers of values are quality, price and convenience. In each industry certain factors must be defined of each sub driver in order to find programs for an improvement in value chain;

- Brand value is subjective and intangible assessment of the brand. Sub drivers of brand values are brand awareness, customer attitude towards the brand and brand value perception by the customer. Companies use advertising, public relations and other forms of communication to influence this sub drivers. Aaker defines brand value as a series of advantages and disadvantages, which increase or decrease the value of relevant products or services;

- Relationship value is the tendency of customers to stick with the brand. Sub drivers of relationships value include loyalty programs, programs for special awards, programs aimed at building 
community and programs of acquiring knowledge.

From all the customers who file complaints, between $54 \%$ and $70 \%$ would repeat business with the company, if their complaint is accepted. The figure reaches even $95 \%$ if the customer believes that the complaint was resolved quickly. They usually inform 5 persons about the procedure if it was good managed, or 9 or more persons, if they are not satisfied (Kotler P., Keller, 2006). Aaker believes that, in any company, consumer satisfaction is produced at the top, not the bottom, like most managers tend to believe. It is the direct rezult of employee satisfaction. Berry and Parasuraman have identified three approaches to retain customers: additional financial benefits, extra social benefits and additional structural links (Kotler P., Keller Kevin L., 2006). According to Kotler, CRM includes all business activities from acquisition and identification the most valuable customers, competition analysis, creation new distribution channels, to motivation of employees and revealing the reasons that influence consumer loyalty or moving to the competitor. However, there is no one-size that fits all customer loyalty program. Each company must know market and demand characteristics in order to retain existing consumers, using innovation and adding value to the basic product or service, because consumers expect to be addressed with messages relevant to them.

\section{Frequency programs (FPs): Examples}

The concept that might be helpful in the advertising development process, based on information obtained from the consumers' lifestyle, is related to rewards that people seek for their activities and interests. Do target consumers get rewarded for doing something good for others, or have their rewards resulting from their personal interests and activities? For example, if the target consumer sees the reward in doing something for others, then it would be better to show him, that with buying the product, he is doing the right thing for his family (Plummer J.T., 1974:37). It is believed that there are five types of power through which groups can influence on individual behavior: legitimate, expert, referent, power of force and the power of rewarding (Wilkie L.W., 1990:432433).

The introduction of the CRM into operating system along with loyalty programs (rewards), companies change, step by step, consumer behavior from the new cautious user to loyal user with a feeling of confidence and trust. It was noted that the rewards, directly associated with the product, are more effective than ones that have no similarity with it. Also, more effective on the consumer's satisfaction are rewards that are immediately realized or consumed from ones which will realize in the future (Evans M., et al. 2006:77).

The concept of segmentation, called frequent users is increasingly gaining its importance in the tourism industry. For example, airlines programs of frequent flights are aimed at heavy users, given that they are business travelers, and also buy expensive tickets. Members of the British Airways Executive Club, as blue cards users, get free air miles every time they travel and receive other benefits when booking a flight and register. As the intensity of use increases, club members receive silver and gold cards, both providing additional benefits and services (Živković R., 2009:15).

Miraval Arizona, a spa located in Tucson, USA, has launched a loyalty program called "Authentic Circle." The program features three levels of membership based on the frequency of consumer stays. Benefits include room upgrades, priority access to activities, invitations to program events and resort credits. Members also receive a complimentary subscription to a branded digital 
magazine. The loyalty push is in the reviving existing relationship with guests after they return home through direct mail and e-mail about details of the program's benefits.

Portola HotelÆSpa, Monterey, California, USA, has launched in 2011 the first hotel loyalty program for kids (http://www. portolahotel.com). The Portola Pirates loyalty program offers additional rewards for return child guests. After children experience the Portola Pirates scavenger hunt during their first visit, families will receive different complimentary rewards during a third, fourth and fifth visit. InterContinental hotel is running frequent promotions that let customers redeem as few as 5,000 points for some rooms. Hotel Marriott Rewards has launched a promotion that offers members every third night free when redeeming two consecutive nights. Calculating how to earn and spend points on rooms can be more complicated, because each company has its own formula. Marriott Rewards, for instance, gives 10 points for each dollar spent at most of its hotels (a $\$ 250$ room will net you 2,500 points). Hilton hotel program is the only program that counts award stays toward elite status; allows hotel-stay credit to be used for both HHonors points and airline miles (more than 60 participating carriers).

Due to its popularity, there are a specialized online sites pointmaven.com and flyertalk.com, that posts up-to-the-minute loyalty program news.

For the purposes of loyal consumers purchase recording, management software is widely used today, designed specifically for the service and retail industries. "Salon\&Spa 8 " is for Salons, Spas and Medi-spas while "iTracRetail 8" is suited to those providing service and/or retail products. Both programs maximize sales efficiency, monitor business performance, manage customer and inventory information, maintain customer and staff schedules and provide customer loyalty and incentive programs (rewards, coupons, sales, points, gift certifi- cates and discount cards, special savings for "loyal" customer groups, advanced notice on sales only for "loyal" customers, etc.).

\section{Conclusion}

In a market where there is an intense competition, it is necessary to bear in mind that consumers perceive all the details when they decide to whom they will give their trust. The progress in technology has brought to consumers a faster and more transparent access to all information. Today's consumers are better informed about products and services offered to them on the global market, which makes it more difficult for companies to compete in gaining their loyalty.

Accordingly, reward programs will allow consumers to get an impression that their purchases obtain additional value, apart from the one that was bought in a form of a tourism product or service. In order to reach customer loyalty, companies must create customer value chain. Maximizing the value of customers means fostering longterm relationships with them. In order to achieve closer relationships with customers it is necessary that each tourism company identifies its present customers as well as potential ones, create a database and constantly invests in finding new customers, but still retaining existing ones. Particularly important is the fact that loyal consumer enables sustainable competitive advantage.

The given examples show that major role in the formation of customer loyalty have their trust and sense of belonging. Therefore, an imperative in the business of tourism companies is the introduction of a loyalty program as a way of consumers' appreciation, who are frequent in their purchases of products and services and thus, make a company's profits stable for a longer period of time. 


\section{References}

Aaker D., Kumar V., Day G., (2008), Marketinško istraživanje, deveto izdanje, CID Ekonomski fakultet, Beograd, (pp. 684-694).

Evans M., Jamal A., Foxall G., (2006), Consumer Behaviour, John Wiley\&Sons, Ltd, England, (pp. 264-286).

Griffin J., Lowenstein W. M., (2002), Customer Winback: How to Recapture Lost Customers - and Keep Them Loyal, Jossey-Bass, A Wiley Company, San Francisko.

Keaveney S., M., (1995), Customer Switching Behaviour in Service Industries: An Exploratory Study, Journal of Marketing, Vol 59, (pp.71-82).

Kotler P., Keller Kevin L., (2006), Marketing menadžment, 12 izdanje, Data status, Beograd,(pp. 141-160; 372).

Lindstrom M., (2007), Brand sense-gradenje moćnih brendova pomoću čula dodira, ukusa, mirisa, vida i sluha, Mass M. International, Beograd.
Plummer J.T., (1974), The concept and application of life style segmentation, Journal of Marketing, 38(1), (pp. 37).

Reichheld F., (1996), Learning from Customer Defections, Harvard Business Review, (Vol 74 , No 2).

Smith P., (2002), Marketinške komunikacije integralni pristup, Clio, Beograd, (pp. 491).

Veljković S., (2006), Marketing usluga, CID, Beograd, (pp. 184; 190-195).

Wilkie L.W., (1990), Consumer Behavior, 2nd ed., John Willey and Sons, Inc., New York, (pp. 432-433).

Živković R., (2009), Ponašanje i zaštita potrošača u turizmu, Univerzitet Singidunum, Beograd, drugi izmenjeno i dopunjeno izdanje, (pp. 15).

http://www.portolahotel.com

http://www.pointmaven.com

http://www.flyertalk.com

http://www.travelandleisure.com/articles/ best-hotel-loyalty-programs?cnn=yes 